\title{
Cork oak (Quercus suber L.) wood growth and vessel characteristics variations in relation to climate and cork harvesting
}

\author{
Sofia Leal · Elsa Nunes $\cdot$ Helena Pereira
}

Received: 25 August 2006/Revised: 17 January 2007 / Accepted: 24 April 2007/Published online: 5 June 2007

(C) Springer-Verlag 2007

\begin{abstract}
Variations in tree ring growth of Quercus suber L. were analysed using dendrochronological techniques on cork oak discs from trees harvested in the cork producing region of Alentejo, Portugal. A tree-ring chronology containing a strong common signal and covering the period from 1970 to 1995 was build for ca. 30-year-old cork oaks never submitted to cork harvesting using 14 trees that crossdated satisfactorily out of 30 sampled trees. The tree ring indices correlated positively with September temperature $(r=0.48, P<0.05)$ and very strongly with precipitation totals from previous October until current February ( $r=0.82, P<0.001)$ showing that the water stored in the soil during the autumn and winter months prior to the growing season has a primordial effect on the growth of the given season. The effects of cork harvesting were analysed by comparing mean ring width, mean annual vessel area, vessel density $\left(\mathrm{n}^{\circ}\right.$ vessels $\left./ \mathrm{mm}^{2}\right)$, and vessel coverage (percentage of transverse surface occupied by vessels) between three mature cork oak trees and three young trees, for the period from 1987 to 1996 , corresponding to the growth between two consecutive cork removals in the case of mature trees. In 1988, 1989 and 1996 (corresponding to the first and second years after cork removal, and 1996 to a year of cork removal), the ratios between ring widths of young versus mature trees was twice that for the rest of the period. However, an effect of cork removal indicated by eventual alterations in vessel size and distribution in the
\end{abstract}

Communicated by Rainer Matyssek.

S. Leal $(\bowtie) \cdot$ E. Nunes $\cdot$ H. Pereira

Centro de Estudos Florestais, Instituto Superior de Agronomia,

Tapada da Ajuda, 1349-017 Lisbon, Portugal

e-mail: spleal@yahoo.co.uk wood rings corresponding to the years 1988, 1989 and 1996 in the mature cork oaks was not observed.

Keywords Quercus suber L. · Wood anatomy · Wood vessels · Tree rings - Dendrochronology · Precipitation · Cork harvesting

\section{Introduction}

Cork oaks (Quercus suber L.) are usually found in agroforestry systems that are characterized by sparse forests exploited for cork production, in association with agricultural crops and pasture for cattle grazing. These systems are common in south-western Europe, in Portugal and Spain, where they are called respectively montado and dehesa (Pereira and Tomé 2004).

The Quercus suber is a species known for producing cork as a thick outer layer in the bark around stem and branches. This cork layer can be removed since the tree is capable of forming a new cork bark by adding new layers of cork every year, therefore allowing a sustained cork production during the cork oak lifetime. Cork removal is performed for the first time when the tree is around 25-30 years old (with a breast height perimeter above $70 \mathrm{~cm}$ ) and afterwards every nine or more years in order to obtain a cork with a thickness adequate for industrial processing. Cork is used for several industrial purposes, but mainly for production of cork stoppers for wine bottling.

The research on cork oak has been so far focused on issues related to cork production and not much has been investigated on the tree growth and stem wood characteristics, namely on the effect of climate and cork removal on wood growth. 
Cork oak growth is sensitive to climate and its seasonal changes, mostly to precipitation (Costa et al. 2001). The effect of precipitation has been more thoroughly studied in relation to the cork and good correlations were reported between fall and winter cumulated rainfall and cork ring width in mature trees under cork production in several regions (Caritat et al. 2000; Costa et al. 2001). For wood growth, a similar relationship was reported albeit it referred to only one tree (González-Adrados and Gourlay 1998).

Cork removal has an immediate effect of water loss by the exposed surface of live tissues with the subsequent response of stomata closure, leading to interruption of the nutritional functions, only returning to normal after 2430 days following the regeneration of the phellogen and production of the first thin layers of cork (Santos 1940; Oliveira 1995). The activity of the vascular cambium decreases and the wood growth stops (Natividade 1938). Wood anatomy is also affected by the cork removal resulting in an irregular distribution of vessels and also loss of typical earlywood/latewood transition (Lupi 1938).

The effect of cork removal on tree growth has been studied by measuring over cork stem radial growth, i.e. with dendrometers, and for very young cork oaks no significant effect was reported (Fialho et al. 2001). However the major component of the tree growth in over-bark diameter corresponds to the increments in cork (Costa et al. 2001), which increase in the 2-3 years following cork removal (Caritat et al. 1996; Ferreira et al. 2000; Costa et al. 2002b), while wood growth is low and shows narrow and undefined annual rings (Lupi 1938; Gourlay and Pereira 1998).

One of the possible reasons for the few studies on wood growth in cork-oaks lies in the difficulty of the sampling of trees for wood ring measurements since strict legal restrictions apply to the harvest of cork oaks and felling authorisations of living trees are given only in a few situations, namely when public interest issues are involved. The number of healthy productive trees available for study is therefore very limited.

This paper reports the results of a dendroclimatological analysis of the effects of climate on wood annual growth in young cork oaks. The effect of cork removal on wood growth and anatomy was also analysed through a comparative study between mature cork oaks in full cork production and younger cork oaks before the first cork extraction, where wood ring widths and vessel characteristics were measured during a full 9-year cork production cycle.

\section{Materials and methods}

The cork oak trees used for this study come from authorized fellings carried out in the cork production region to the south of river Tagus, in the Alentejo region of southern Portugal. Figure 1 shows the location of the Alentejo region (administrative borders) as well as the northern climatic border given by the Tagus river (Alentejo means beyond the Tagus river).

The climate in the region is described using the data from nine meteorological stations (Alcácer do Sal, Alvalade, Beja, Elvas, Évora, Mértola, Pegões, Portalegre, and Viana do Alentejo, Fig. 1), which are considered by the National Meteorology Institute as the ones that best characterise the climate of the Alentejo region. Figure 2 shows the mean temperature and rainfall distribution for the region as the mean values of these stations. The climate is typically mediterranean, with the highest mean temperatures occurring in July and August $\left(\sim 24^{\circ} \mathrm{C}\right)$, when the precipitation is close to zero, and a dry season extending from May through September. The average annual temperature for the region is $16^{\circ} \mathrm{C}$ and the average annual precipitation is $600 \mathrm{~mm}$.

The harvested trees were isolated trees without betweentree competition from low-density stands typical of the

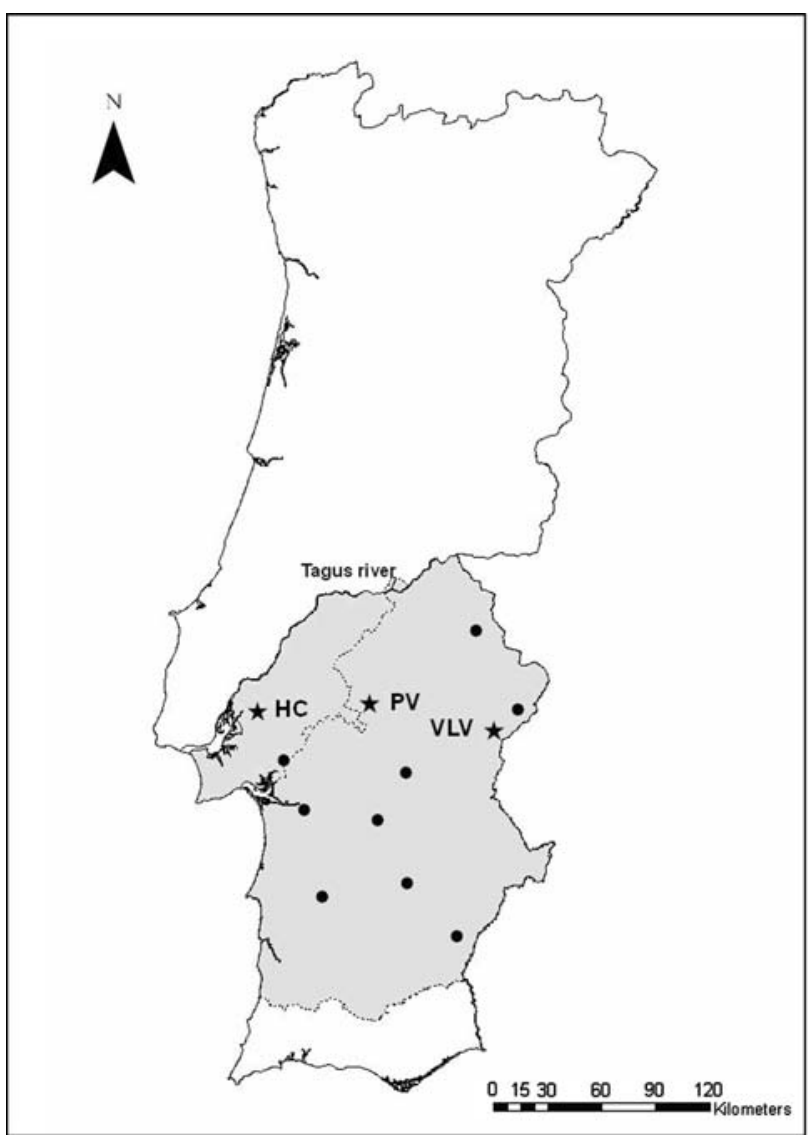

Fig. 1 Location of the study sites and climatic stations (black circles), with the Alentejo administrative region borders (dashed lines) and the river Tagus that climatically defines the study region (grey area) 


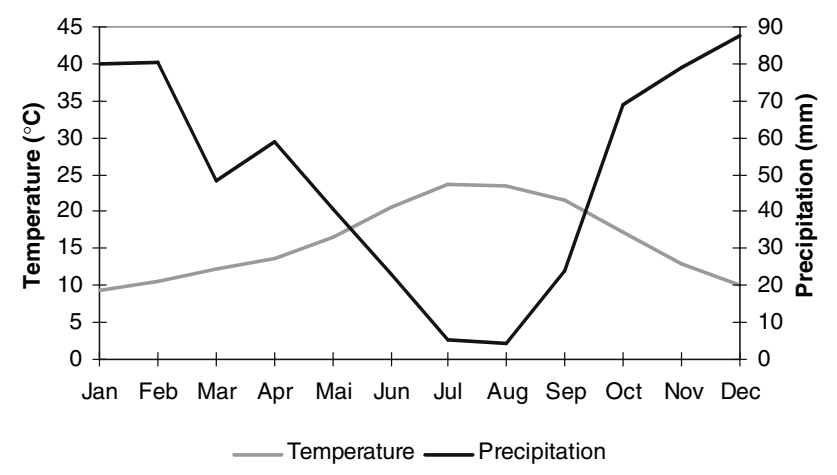

Fig. 2 Climatic diagram for the study region

montado system. They were harvested from three locations (Fig. 1) as described below.

Effects of climate on wood growth

A total of 30 trees were harvested in VLV-Herdade da Tapada Real, Vila Viçosa, Évora (Fig. 1). The trees were around 30 years old, never submitted to cork harvesting, and presented good vitality and phytosanitary conditions. One wood disc with approximately $5 \mathrm{~cm}$ of thickness was cut at $1.30 \mathrm{~m}$ of tree height.

After an acclimatisation period of 4 weeks in a chamber at $25-30^{\circ} \mathrm{C}$, the wood discs were sanded through several successively decreasing grades of grit in order to remove surface irregularities that could obstruct the identification of tree ring limits. Ring boundaries were observed at $70 \times$ magnification under a low power microscope, and marked in each wood disc along two radial directions at a minimum of $90^{\circ}$ of distance. The patterns in the sequences of tree ring were graphically represented using skeleton plots (Stokes and Smiley 1968). The tree rings were dated and missing or false rings were identified by crossdating, first the two plots from the same tree, and then between plots representing different trees.

The ring widths from successfully crossdated trees were measured to the nearest $0.01 \mathrm{~mm}$ using a Bannister increment measurer. A final crossdating quality control was preformed on the tree-ring series with COFECHA (Holmes 1994), a computer program designed to identify possible problems and measurement errors. Each pair of measurement series from one tree was averaged to minimise within tree variation, creating mean-tree series of measurements.

Standardisation was used to isolate the contribution of climate by removing the influence from other factors, such as disturbances, tree's individual variability or age-dependent decreasing trend in ring width. This consisted in fitting a curve to the growth trend of each tree-ring series, and dividing the tree-ring widths by the values of this fitted curve creating a series of dimensionless tree-indices with means of 1.0 (Fritts 1976). The program ARSTAN
(Holmes 1994) was used to execute the standardisation and the most conservative approach, the negative exponential curve, was applied to our data because it works well with trees from open-canopy stands where growth is more-orless undisturbed (Cook and Briffa 1990b), which is the case of the present study. The obtained tree-ring indices for the several trees were averaged together by calendar year producing one tree-ring chronology.

The following statistical indicators (Cook and Kairiukstis 1990a) were used to assess the signal strength, or amount of common variability present in all trees, since a high common signal in a site indicates that common environmental factors, such as climate, control tree growth:

1. Effective chronology signal $\left(r_{\text {eff }}\right)$, a chronology signal estimate based on correlation coefficients which incorporate both within- and between-tree signals

$r_{\mathrm{eff}}=\frac{r_{\mathrm{bt}}}{r_{\mathrm{wt}}+\frac{1-r_{\mathrm{wt}}}{c}}$

where $r_{\mathrm{wt}}$ is the within-tree signal calculated as the average of the correlation coefficients between index series from the same tree for all the trees, $r_{\mathrm{bt}}$ is the between-tree signal obtained by averaging the correlation coefficients calculated for all the possible pairs of series drawn from different trees, and $c$ is the number of cores per tree.

2. Mean Sensitivity $\left(m_{\mathrm{sx}}\right)$, a measure of how sensitive a tree-ring series is, i.e. how much do tree ring widths vary in comparison with previous years

$m_{\mathrm{sx}}=\frac{1}{n-1} \sum_{t=1}^{t=n-1}\left|\frac{2\left(x_{t+1}-x_{t}\right)}{x_{t+1}+x_{t}}\right|$

where $x_{t}$ and $x_{t+1}$ are the ring widths of a series in a given year and in the following, and $n$ is the number of years. Single values of the sensitivity range between zero, when there is no difference between consecutive rings, and two, when a zero value occurs next to a non-zero;

3. Expressed population signal (EPS) quantifies to which degree the chronology signal is expressed when series are averaged

$\mathrm{EPS}=\frac{r_{\mathrm{eff}}}{r_{\mathrm{eff}}+\frac{1-r_{\mathrm{eff}}}{n}}$

4. Signal-to-noise ratio (SNR), an expression of the strength of observed common signal between trees

$\mathrm{SNR}=\frac{n r_{\mathrm{bt}}}{\left(1-r_{\mathrm{bt}}\right)}$

The relationships between the tree-ring chronology and the time-series of climate variables (average monthly 
temperatures and monthly precipitation totals from September, from previous year, to October, from current year) were analysed using Pearson correlations calculated over the period 1970-1995. A linear regression model was applied to estimate the climate variable showing the best agreement with tree-ring indices using the chronology treering indices as independent variable.

Effects of cork harvesting on wood growth and anatomy

Six trees, including three mature trees under full cork production with an age above 60 years and three young trees from which cork was never removed and with an age around 35 years, were collected respectively from HC, Herdade da Carvoeira, Benavente, Santarém; and PV, Pavia, Mora, Évora (Fig. 1).

From each tree, one stem disc was taken at $1.3 \mathrm{~m}$ height. Radial strips, free of damaged areas, covering the whole wood growth on the radial direction (from pith to bark) were cut from each disc. Per disc three radial strips and two radial strips, respectively from the mature and the young cork oaks, were prepared for measurements. Each strip was split axially in two paired sub-strips, one kept for ring measurements and the other for vessel measurements. The measurements were performed for all the trees on the sections of the radial strips corresponding to the years between 1987 and 1996. This 10-year period is situated between the two last subsequent cork removals in the mature trees (respectively in 1987 and 1996). For each calendar year, mean tree ring-width values were calculated for each type of tree (non-debarked and debarked).

The sub-strips for ring measurements were polished on a belt sander, through three grades of grit and the tree rings were marked on the wood with a thin pencil by observation with a low power microscope. Ring width measurements were made on the images obtained from the samples, at $25 \times$ magnification, with a low power microscope (Olympus SZH10) connected to a video camera (JVC model TKC1380E), using the image analysis software LEICA Qwin.

The transversal surfaces of the radial sub-strips for vessel measurements were sanded manually, through three grades of grit, and rubbed with a white wax crayon to impregnate the vessels in order to distinguish them from the rest of the tissues under a low power microscope. The adopted protocol proved the best for cork oak wood after trying out several methods of surface cutting, smoothing and vessel enhancement.

Sequential images were collected from the wood cross sections, using a low power microscope (Olympus SZH10) with a video camera (JVC model TK-C1380E), and stored in JPEG graphic format using the image analysis software
LEICA Qwin. With a total magnification of $30 \times$, each image (measuring frame) covered $2,612 \mu \mathrm{m}$ on the radial direction and $1,592 \mu \mathrm{m}$ on the tangential direction. The section of the radial strip under study was covered by the successive images. The images were converted to binary format and, after applying threshold and minimum size settings, vessels were clearly identified as separate objects. In each measuring frame the area of each vessel was automatically recorded. The average vessel area, vessel density (number of vessels per square millimeter), and vessel coverage (percentage of cross sectional area covered by vessels) were calculated for each growth ring. For each calendar year, mean vessel variables values were calculated for each type of tree (non-debarked and debarked).

The two types of trees were compared by calculating, for each calendar year, the ratios between non-debarked and debarked trees of the mean values of the wood variables (ring-width, vessel area, vessel density, vessel coverage).

\section{Results}

Effects of climate on wood growth

During the period from 1967 to 1995 , the ring widths from the trees used for chronology construction averaged $2.50 \mathrm{~mm}$, varying between an average minimum of $0.78 \mathrm{~mm}$ and an average maximum of $5.76 \mathrm{~mm}$. Tree ring widths tend to decrease with cambial age from an average of $3.27 \mathrm{~mm}$ in the beginning of cambial activity to an average of $1.06 \mathrm{~mm}$ at 26 years of age. Figure 3 shows an example of one series of tree-ring measurements from VLV site and the resulting tree-ring indices after standardization. The VLV tree-ring chronology (Fig. 4) was built using only 14 out of the 30 sampled cork oak trees because the remaining trees did not crossdate satisfactorily. Basic statistical indicators of chronology signal strength are presented in Table 1 and they indicate a strong common signal.

The correlation analysis between tree-ring indices and climatic variables reveals a strong positive correlation $(r=0.82, P<0.001)$ between tree growth and the precipitation accumulated before the start of the growing season, i.e. precipitation totals from previous October until current February; and a positive correlation (0.48, $P<0.05)$ between tree growth and September average temperature (Table 2).

Precipitation estimates based on a regression model using tree-ring indices as predictors show a very good overall agreement with the actual precipitation totals that occurred from previous October until current February (Fig. 5). 

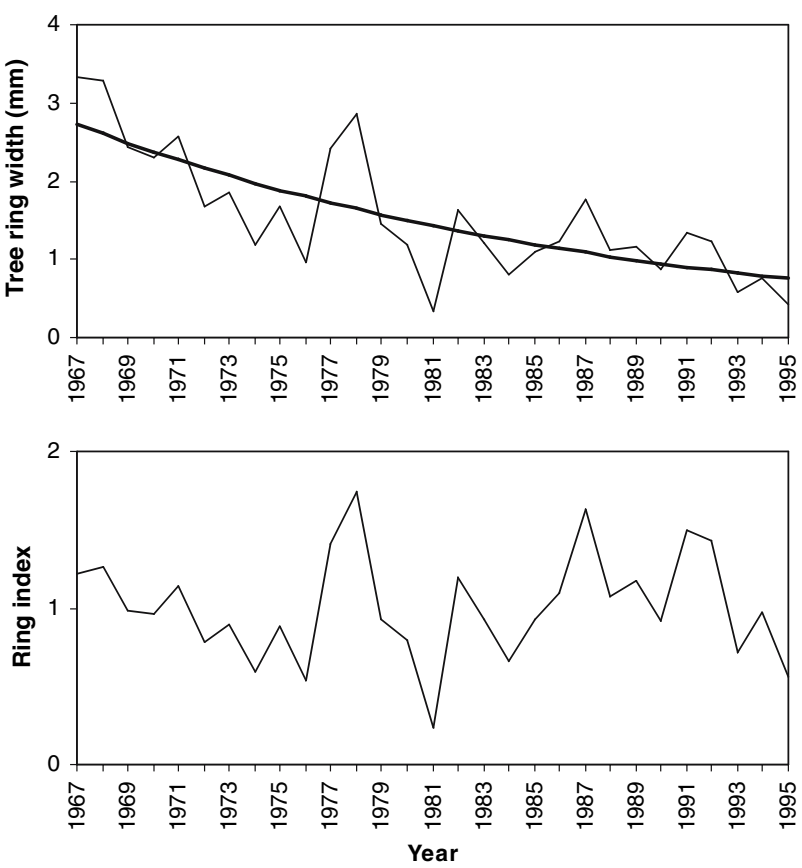

Fig. 3 Example of one series of cork oak tree ring measurements before standardization, raw tree ring widths (upper graph), and after standardization, tree ring indices (lower graph)

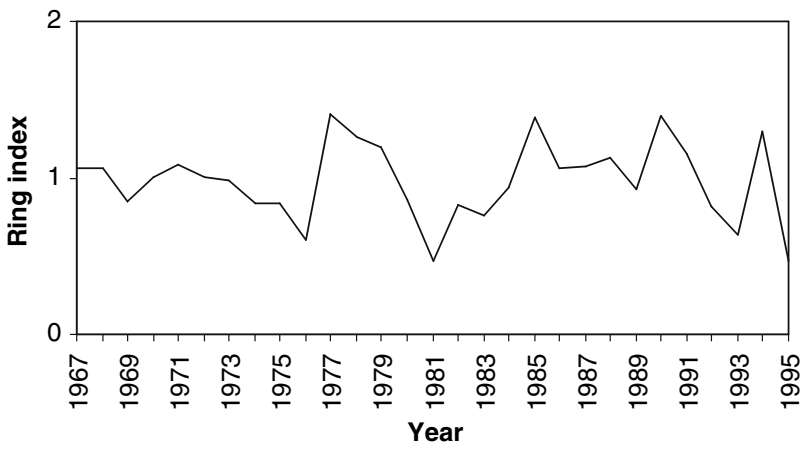

Fig. 4 Cork oak tree ring chronology for the VLV study site

Table 1 Basic statistical indicators of chronology signal strength

\begin{tabular}{llll}
\hline$m_{\mathrm{sx}}$ & $r_{\text {eff }}$ & EPS & SNR \\
\hline 0.267 & 0.349 & 0.866 & 5.27 \\
\hline
\end{tabular}

$M_{s x}$ Mean Sensitivity, $r_{\text {eff }}$ Effective chronology signal, EPS Expressed Population Signal, SNR Signal-to-Noise Ratio

Effects of cork harvesting on wood growth and anatomy

The cork oaks showed a semi-diffuse porosity. The difference in vessel size between earlywood and latewood was higher in the young cork oaks therefore allowing a better ring definition. The identification of wood rings was difficult in the mature trees under cork production, and a
Table 2 Correlation coefficients between the VLV tree ring chronology and series of mean temperature and precipitation for several months

\begin{tabular}{|c|c|c|c|c|}
\hline Season & Temperature & Significance & Precipitation & Significance \\
\hline \multicolumn{5}{|l|}{ Previous year } \\
\hline September & 0.09 & NS & 0.18 & NS \\
\hline October & 0.02 & NS & 0.36 & NS \\
\hline November & -0.29 & NS & 0.38 & NS \\
\hline December & 0.33 & NS & 0.42 & $P<0.05$ \\
\hline \multicolumn{5}{|l|}{ Current year } \\
\hline January & -0.07 & NS & 0.44 & $P<0.05$ \\
\hline February & 0.24 & NS & 0.45 & $P<0.05$ \\
\hline March & -0.10 & NS & -0.11 & NS \\
\hline April & 0.00 & NS & 0.02 & NS \\
\hline May & -0.08 & NS & -0.05 & NS \\
\hline June & -0.37 & NS & 0.10 & NS \\
\hline July & -0.17 & NS & 0.26 & NS \\
\hline August & -0.19 & NS & -0.25 & NS \\
\hline September & 0.48 & $P<0.05$ & -0.38 & NS \\
\hline October & 0.08 & NS & 0.25 & NS \\
\hline $\begin{array}{c}\text { December- } \\
\text { February }\end{array}$ & - & - & 0.68 & $P<0.001$ \\
\hline $\begin{array}{l}\text { October- } \\
\text { February }\end{array}$ & - & - & 0.82 & $P<0.001$ \\
\hline
\end{tabular}

$N S$ not significant

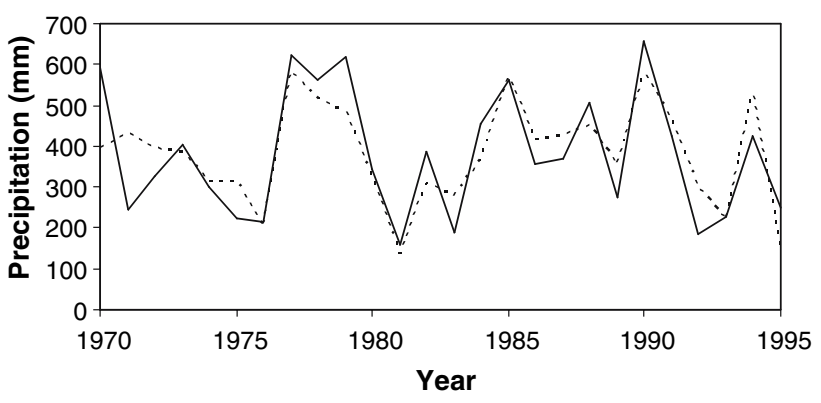

Measured precipitation ...... Estimated precipitation

Fig. 5 Real autumn and winter precipitation, from October prior to the growing season until February, versus the precipitation estimated using a climate-growth model; data and calculations for the years 1970-1995

careful visual observation on the several radii of each stem disc and the superposing of the curves were necessary.

Overall, during the period from 1987 to 1996, the wood ring width ranged between 1.34 and $6.20 \mathrm{~mm}$, averaging $2.61 \pm 1.12 \mathrm{~mm}$, for the young trees, and between 0.68 and $3.20 \mathrm{~mm}$, averaging $1.63 \pm 0.68 \mathrm{~mm}$, for the mature trees. Vessels were larger and more numerous in the young trees. In the 1987 to 1996 period, the vessel area averaged $23,758 \pm 4,851 \mu \mathrm{m}^{2}$ and $17,827 \pm 3,390 \mu \mathrm{m}^{2}$ respectively 
for young and mature trees, and the vessel density $6.00 \pm 1.74$ vessels $/ \mathrm{mm}^{2}$ and $5.25 \pm 1.04$ vessels $/ \mathrm{mm}^{2}$ respectively (Fig. 6). The vessel coverage, which represents the conductive area, was lower in the mature cork oaks in comparison with the young trees $(9.3 \pm 2.0 \%$ vs. $13.9 \pm 4.2 \%)$.

With the exception of 1988, 1989 and 1996, the values for ring-width, mean vessel area, vessel density, and vessel coverage were on average 1.4 times larger in the case of young trees (Fig. 7). In these years, the growth rings of mature trees reached the lowest increments (on average $1.10,1.02$, and $1.19 \mathrm{~mm}$, respectively, in 1988, 1989, and 1996) and were much thinner when compared with the growth of the young trees in the same years (on average, young trees ring widths were 2.8 times larger). The years of 1988 and 1989 corresponded to the first and second years after cork removal, and 1996 to a year of cork removal. As regards the wood anatomy, an effect of cork removal as indicated by eventual alterations in the vessel characteris-
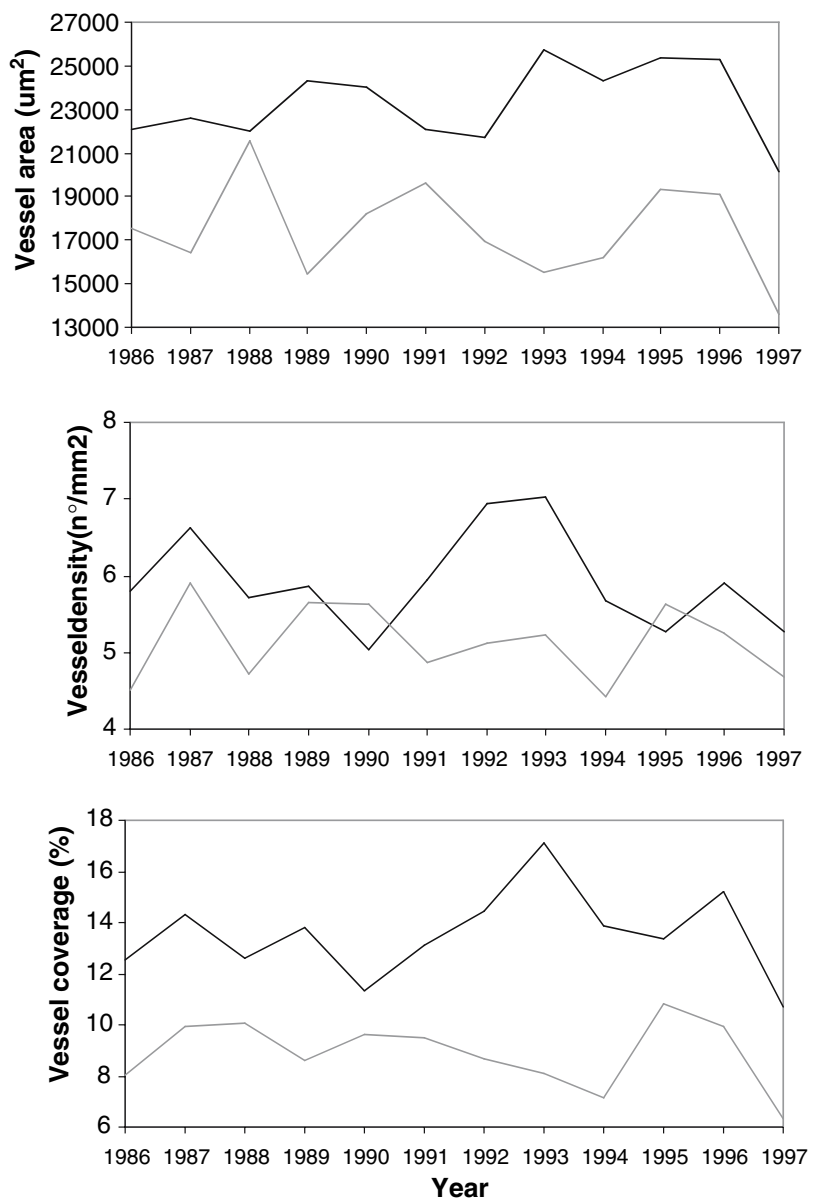

Fig. 6 Variations in mean vessel area (upper graph), vessel density (middle graph), and vessel coverage (lower graph), along a 10-year period comprised between two cork extractions, for young (black lines) and mature (grey lines) cork oak trees

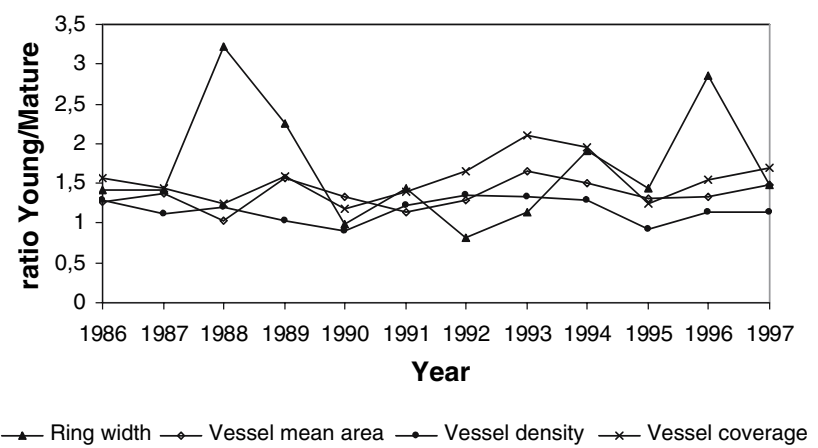

Fig. 7 Ratios between young and mature trees' mean values for the ring variables (ring width, vessel area, vessel density, and vessel coverage), along a 10-year period comprised between two cork extractions

tics in the wood rings corresponding to the years 1988, 1989 and 1996 in the mature cork oaks was not observed. However the mature cork oaks with cork extractions showed smaller vessels and less gradation of vessel size within the ring, resulting in poorly defined rings.

\section{Discussion}

The knowledge on a species' growth characteristics and on effects that climatic variables and silvicultural management decisions have on tree growth is obviously a key issue for assessing and preserving the sustainability of the forests. This is more so when the trees are managed in a sustained exploitation of non-wood components that may have a detrimental effect on the tree growth, and when the forests are in ecologically sensitive areas and balance between several multifunctional options. This is the case with the cork oak (Quercus suber) which is exploited in agroforestry systems in the prevalently poor regions of southern Europe and North Africa with successive cork extractions during the tree lifetime that may be a cause of growth decline (Pereira and Tomé 2004).

However, very little is known on cork oak growth, namely on the wood component of the tree growth, e.g. the cambium activity, and nothing has been published on the quantification of the effects of climatic factors and cork removal on it. The existing growth and yield models for the cork oak are based on over-bark diameter growth and on cork growth (Tomé et al. 1998; Pereira and Tomé 2004; Sánchez et al. 2005, 2006) and most modelling efforts were focused on predicting cork weight production (i.e. Ferreira and Oliveira 1991; Fonseca and Parresol 2001; Ribeiro and Tomé 2002; Vásquez and Pereira 2005).

The wood ring identification and width measurement made in the present study were difficult tasks due to the fact that Quercus suber rings are hard to distinguish, 
varying in width along the tree perimeter and with the possible presence of false rings. The use of other techniques such as microdensitometry does not solve this problem, as also reported by Knapic et al. (2007). Observation of wood discs seems therefore a requirement for ring width studies in mature cork oaks, confirming the results reported by Gourlay and Pereira (1998). This fact adds extra difficulties to perform cork oak wood growth studies due to the legal restrictions on tree harvesting. Therefore, information on wood growth measured in cork oak stem discs is valuable even if the number of samples available is not as high as in conventional ring analysis.

\section{Effects of climate on wood growth}

Cork oak trees grow well with annual rainfalls between 500 and $1,600 \mathrm{~mm}, 400 \mathrm{~mm}$ being the minimum required (Natividade 1950). There was an overall good agreement $(r=0.82, P<0.001)$ between precipitation totals from previous October to current February and ring indices in young cork oaks; September temperature had also a positive effect on tree growth $(r=0.48, P<0.05)$ but not as strong as precipitation (Table 2 and Fig. 5). Other authors have reported wood growth in Quercus suber to show interannual fluctuations related with variations in cumulated precipitation (González-Adrados and Gourlay 1998; Costa et al. 2001). Other oak species growing in Portugal (Nabais et al. 1999) and Spain (Garcia-González et al. 1997) were shown to provide clear climatic signals as well. In semiarid regions in general and particularly in some geographical regions like Spain, North Africa, southeast USA and China, tree-ring growth is highly correlated with rainfall (e.g. Richter and Eckstein 1990; Till and Guiot 1990; Stahle and Cleaveland 1992; Hughes et al. 1994).

The influence of water supply on tree growth is well studied (e.g. Kozlowski et al. 1991). The quantity as well as the quality of wood formed annually is strongly affected by water supply (Fritts 1976). In the case of the present study, the water stored in the soil during the autumn and winter months prior to the growing season has a primordial effect on the growth of the trees during the given season.

Effects of cork harvesting on wood growth and anatomy

The growth period studied here corresponded to a 10-year period between two cork extractions (1987 and 1996) which represents the so-called 9-year cork production cycle extending between two consecutive cork extractions (the year of cork extraction is counted as a half-year in cork production). The effect of cork removal on growth was therefore searched for on the wood rings of these years as well as on the following years (1988 and 1989).
Indirect calculations have estimated an average radial wood increment of $1.3 \mathrm{~mm}$.year ${ }^{-1}$ in one 8-year period following a cork extraction in mature cork oaks in full cork exploitation (Costa et al. 2002b) and the only published references to direct wood ring width measurements on cork oak stem discs refer a mean annual growth of $4.2 \mathrm{~mm} \mathrm{year}^{-1}$ in the first 30 years of tree growth (Knapic et al. 2007) and values ranging from 1 to $4 \mathrm{~mm}$.year ${ }^{-1}$ in mature cork oaks (Gourlay and Pereira 1998; González-Adrados and Gourlay 1998).

The comparison of the mean annual individual growth curves for the mature trees with those for the young trees showed that the main differences appeared in the years of cork removal and in the following years (Figs. 6, 7). In the mature cork oaks the ring width was very low in 1988 and $1989(1.10 \mathrm{~mm}$ and $1.02 \mathrm{~mm})$, the years following the cork removal in 1987, and the same happened in 1996 $(1.19 \mathrm{~mm})$, corresponding to a year of cork removal. However, the years of 1987, 1988 and 1996 had high precipitation, leading to wide rings in the young cork oaks (3.04, 3.56 and $3.39 \mathrm{~mm}$, respectively) and 1989 had an average precipitation with an average ring width $(2.30 \mathrm{~mm})$. Obviously, cork removal decreases the wood growth in the year of cork removal or in the following years, which was not overcome by favourable water conditions. This confirms reports about a marked decrease in wood ring width two to three years after cork removal (Lupi 1938; González-Adrados and Gourlay 1998; Gourlay and Pereira 1998) and about an increase in cork growth during this period which is said to affect wood growth negatively (Natividade 1950; Caritat et al. 1996; Ferreira et al. 2000; Costa et al. 2002b).

However, a wood growth reduction was not observed in the year of cork removal in 1987. The reason is not known, and details on the history of the trees in that period were not recorded, namely the timing of the cork extraction. In fact extraction of cork is made between June and August, and studies on the seasonality of tree growth have shown that tree radial growth is highest in early spring (Costa et al. 2002a). Therefore a late cork extraction, i.e. in August, would have little influence upon the tree growth in that year. It can be speculated that the timing of cork removal will impact on the wood growth of that year.

The effect of cork removal on cork oak wood growth was estimated by comparing the ratios of wood ring width in mature and in young trees for the period 1990-1995 (free of cork removal stress) and for the years of 1988, 1989 and 1996, when this stress effect was recorded (Fig. 7). These ratios averaged 0.84 in the stress-free years and 0.37 in the stress years $(0.31,0.44$ and 0.35 in 1988 , 1989 and 1996, respectively). This comparison allows estimating an annual reduction of wood growth (ring width) due to extraction of cork of approximately 57\% in 
those years. Considering that the cork removal stress effect would be registered in 2 years of the 9 years of the cork production cycle, this allows a rough estimate of a reduction of wood growth in that cycle of $13 \%$. Should the effect extend to 3 years (e.g. including the year of cork removal and the next 2 years), the reduction in wood growth would be $19 \%$.

The reduction in wood radial growth has a practical consequence of reducing the tree perimeter and therefore the surface area that can be used for cork production (stripped surface) and therefore the obtainable cork weight. This is due simultaneously to the perimeter reduction as well as the allowed stem height for cork extraction that is a legally enforced factor (debarking coefficient) based on tree perimeter (Pereira and Tomé 2004). This should be taken into account on long term cork yield modelling and the timing of the first cork extraction and the periodicity of subsequent extractions should be economically balanced with this evidence.

Vessel variables in young trees vary within the range reported by Leal at al. (2006). The wood anatomy of adult cork oaks undergoing cork extractions clearly differed from that of young trees without any cork extraction. Vessels of adult cork oaks were $25 \%$ smaller and the size difference between earlywood and latewood vessels was lost to a large extent (Fig. 6). This means that the tendency of vessels to become larger with tree age (Gasson 1987; Voulgaridis 1990; Leal et al. 2006) did not occur in this case (considering that the young trees had 33-37 years and the mature trees $63-89$ years). This may be the tree's response to the successive removals of cork, as already referred to by González-Adrados and Gourlay (1998) and Gourlay and Pereira (1998). However an immediate effect was not noticed and no differences in vessel size and density were detected on the wood rings corresponding or following the cork extraction (Fig. 7), although it has been reported that latewood anatomy is affected on the year of cork removal producing smaller cells (Lupi 1938).

\section{Conclusions}

Cork oak tree ring growth in young trees is strongly controlled by the precipitation during the months prior to the growing season, i.e. previous October until current February. It is the water available at the beginning of the growth season, which was stored in the soil during the autumn and winter months, that determines the growth in a given year.

Cork oak wood growth was reduced by the effect of cork extraction and smaller ring widths were formed. The impact of cork removal on the ring width may extend from the year of extraction to the two following years. The wood anatomy, as regards vessel size and distribution, of mature cork oaks undergoing successive cork extractions differed from young trees before cork extraction by smaller vessels and conductive area. Therefore, in long-term tree growth and forest sustainability studies, the impact of the cork removal on the wood growth should be considered.

Acknowledgments Part of this study was made within the European project Suberwood (QLK5-CT-2001-00701), under the 5th Framework Programme. We thank Alexandra Ferreira for help with the preparation and measurements of some of the samples; Sofia Knapic for help in data processing; the Instituto de Meteorologia, in the person of Fátima Espírito Santo, for providing the climatic data; David D. Stahle and Malcolm K. Cleaveland for making available the facilities in the Tree-Ring Laboratory, University of Arkansas, and for the useful advices. The first author acknowledges a scholarship by Fundação para a Ciência e Tecnologia (Portugal), the second author acknowledges financial support from J.N.I.C.T. (Portugal), Fundação Calouste Gulbenkian (Portugal) and Fundação Luso-Americana.

\section{References}

Caritat A, Molinas M, Gutierrez E (1996) Annual cork-ring width variability of Quercus suber L. in relation to temperature (Extremadura, Southwestern Spain). For Ecol Manage 86:113120

Caritat A, Gutiérrez E, Molinas M (2000) Influence of weather on cork-ring width. Tree Physiol 20:893-900

Cook ER, Kairiukstis LA (1990) Methods of dendrochronology: applications in environmental science. Kluwer, Dordrecht

Cook ER, Briffa K (1990) Data Analysis. In: Cook ER, Kairiukstis LA (eds) Methods of dendrochronology: applications in environmental science. Kluwer, Dordrecht, pp 97-162

Costa A, Pereira H, Oliveira A (2001) A dendroclimatological approach to diameter growth in cork-oak adult trees under cork production. Trees 15:438-443

Costa A, Pereira H, Oliveira A (2002) Influence of climate on the seasonality of radial growth of cork oak during a cork production cycle. Ann For Sci 59:429-437

Costa A, Pereira H, Oliveira A (2002) Variability of radial growth in cork-oak adult trees under cork production. Forest Ecol Manage 175:239-246

Ferreira MC, Oliveira AMC (1991) Modelling cork oak production in Portugal. Agroforest Syst 16:41-54

Ferreira A, Lopes F, Pereira H (2000) Caractérisation de la croissance et de la qualité du liège dans une région de production. Ann For Sci 57:187-193

Fialho C, Lopes F, Pereira H (2001) The effect of cork removal on the radial growth and phenology of young cork oak trees. For Ecol Manag 141:251-258

Fonseca T, Parresol BR (2001) A new model for cork weight estimation in Northern Portugal with methodology for construction of confidence intervals. For Ecol Manage 152:131-139

Fritts HC (1976) Tree rings and climate. Academic, London

García-González I, Díaz-Vizcaíno EA, Martínez-Cortizas A (1997) Evidence for a common and a species-specific climatic response of oak and birch on a northern Galician site (NW Spain) by means of multivariate procedures. Dendrochronologia 15:119127

Gasson P (1987) Some implications of anatomical variations in wood of pedunculate oak (Quercus robur L.), including comparison with common beech (Fagus sylvatica L.). IAWA Bull 8:149-166

González-Adrados JR, Gourlay I (1998) Applications of dendrochronology to Quercus suber L. In: Pereira H (ed) Cork Oak and 
Cork. Proceedings of the European Conference on Cork Oak and Cork. Centro de Estudos Florestais, Lisboa, Portugal, pp 162166

Gourlay I, Pereira H (1998) The effect of bark stripping on wood production in cork oak (Quercus suber L.) and problems of growth ring definition. In: Pereira $\mathrm{H}$ (ed) Cork Oak and Cork. Proceedings of the European Conference on Cork Oak and Cork. Centro de Estudos Florestais, Lisboa, Portugal, pp 99-107

Holmes R (1994) Dendrochronology Program Library Users manual. Laboratory of tree-ring research, University of Arizona, Tucson

Hughes MK, Wu X, Shao X, Garfing GM (1994) A preliminary reconstruction of rainfall in North-Central China since A.D. 1600 from tree-ring density and width. Quater Res 42:88-99

Knapic S, Louzada JL, Leal S, Pereira H (2007) Radial variation of wood density components and ring width in cork oak trees. Ann For Sci 64:211-218

Kozlowski TT, Kramer PJ, Pallardy SG (1991) The physiological ecology of woody plants. Academic, San Diego

Leal S, Sousa VB, Pereira H (2006) Radial variation of vessel size and distribution in the wood of cork oak (Quercus suber L.). Wood Sci Technol DOI 10.1007/s00226-006-0112-7

Lupi VB (1938) Descortiçamento dos Sobreiros. Contribuição para o Estudo da sua Influência no Desenvolvimento Lenhoso. Dissertation, Instituto Superior de Agronomia, Universidade Técnica de Lisboa, Lisboa, Portugal

Nabais C, Freitas H, Hagemeyer J (1999) Tree-rings to climate relationships of Quercus ilex L. in NE-Portugal. Dendrochronologia 16-17:37-44

Natividade JV (1938) Técnica Cultural dos Sobreirais II. Descortiçamento. Junta Nacional Cortiça, Lisboa, Portugal

Natividade JV (1950) Subericultura. Direcção Geral dos Serviços Florestais e Aquícolas, Lisboa, Portugal

Oliveira G (1995) Autoecologia do Sobreiro (Quercus suber L.) em Montados Portugueses. Dissertation, Faculdade de Ciências da Universidade de Lisboa, Lisboa, Portugal
Pereira H, Tomé M (2004) Cork oak. In: Burley J (ed) Encyclopedia of forest sciences. Elsevier, Oxford, pp 613-620

Ribeiro F, Tomé M (2002) Cork weight prediction at tree level. For Ecol Manage 171:231-241

Richter K, Eckstein D (1990) A proxy summer rainfall record for southwest Spain derived from living and historic pine trees. Dendrochronologia 8:67-82

Sánchez M, Tomé M, Montero G (2005) Modelling height and diameter for cork oak trees in Spain. For Sci 62:633-643

Sánchez M, Del Rio M, Cañellas I, Montero G (2006) Diameter growth of cork oak: a model for sustainable management. For Ecol Manage 225:262-270

Santos JB (1940) Consequências fisiológicas do descortiçamento. Boletim Junta Nacional Cortiça 20:5-9

Stahle DW, Cleaveland MK (1992) Reconstruction and analysis of spring rainfall over Southwestern U.S. for the past 1000 years. Bull Am Meteorol Soc 73(12):1947-1961

Stokes MA, Smiley TL (1968) An introduction to tree-ring dating. University of Chicago Press, Chicago

Till C, Guiot J (1990) Reconstruction of precipitation in Morocco since 1100 A.D. based on Cedrus atlantica tree-ring widths. Quater Res 33:337-351

Tomé M, Coelho MB, Lopes F, Pereira H (1998) Modelo de produção para o montado de sobro em Portugal. In: Pereira H (ed) Cork Oak and Cork. Proceedings of the European Conference on Cork Oak and Cork. Centro de Estudos Florestais, Lisboa, Portugal, pp 22-46

Vásquez J, Pereira H (2005). Mixed models to estimate tree ovendried cork weight in Central and Southern Portugal. For Ecol Manage 213:117-132

Voulgaridis E (1990) Wood cell morphology characteristics of some oak species and Mediterranean shrubs. Holz Roh Werkst 48:261-267 